\title{
Effects of UV Light Irradiation on Color Changes in Thermally Modified Rubber Wood Based on FTIR
}

\author{
Xiaowen Li,* Tongtong Li, Guanjun Li, Min Li, Quanji Lu, Shaoshan Qin, and \\ Jianing $\mathrm{Li}$
}

To evaluate the effects of chemical changes during thermal modification on the resistance of wood against photodegradation, heat-treated specimens of rubber wood (Hevea brasiliensis) were exposed to ultraviolet light for $384 \mathrm{~h}$. The color changes in the exposed wood surfaces were analyzed using a colorimeter; the chemical changes were monitored using Fourier-transform infrared spectroscopy (FTIR). The photoweathering performances of rubber wood treated at $155^{\circ} \mathrm{C}$ for $2 \mathrm{~h}, 155^{\circ} \mathrm{C}$ for $6 \mathrm{~h}$, and $185^{\circ} \mathrm{C}$ for $2 \mathrm{~h}$ were similar to that of untreated wood, as the lignin did not undergo profound chemical transformation under mild modification conditions. However, compared to untreated rubber wood, the photoaging performances of rubber wood treated at $185^{\circ} \mathrm{C}$ for $6 \mathrm{~h}$ and $215^{\circ} \mathrm{C}$ for $2 \mathrm{~h}$ were notably changed. The transformation process was confirmed by FTIR. A good linear relationship between color change and lignin degradation was observed after mild, but not severe, heat treatment. The concentration of carbonyl groups in the wood specimens generally increased during photoaging, although not all samples showed a good correlation between color change and the concentration of carbonyl groups. Only the photochromic performance of wood changed notably when lignin was extensively modified under severe heat-treatment conditions.

Keywords: Rubber wood; Thermal modification; Color; Photostability; FTIR

Contact information: Rubber Research Institute, Chinese Academy of Tropical Agricultural Sciences, Danzhou, 571737, Hainan, P.R. China;*Corresponding author: Li.xiaowen1983@163.com

\section{INTRODUCTION}

Heat treatment is an environmentally friendly process for modifying wood without adding any chemical agents. During thermal modification, various reactions lead to a decrease in amorphous polysaccharide content and the condensation and demethoxylation of lignin. The chemical changes decrease equilibrium moisture content (Jämsa and Viitaniemi 2001; Wang and Cooper 2005; Esteves et al. 2008a) and increase dimensional stability and durability (Popper et al. 2005; Hakkou et al. 2006), but the literature has shown that the strength properties decrease compared with those of untreated wood (Boonstra et al. 1998; Jämsä et al. 2000; Vernois 2001). Furthermore, the wood color is darkened and modified after heat treatment, which can be attributed to the formation of colored degradation products from hemicelluloses and extractives (Esteves and Pereira 2009).

Hevea brasiliensis (rubber wood) is planted in many countries for the production of rubber latex. After approximately 30 years, a decline in rubber latex production makes further tapping of the trees uneconomical. Felled rubber trees are mostly used for making furniture and panel products, such as plywood, particleboard, and fiberboard (MDF). In a 
previous study ( $\mathrm{Li}$ et al. 2011), heat-treated rubber wood had a beautiful teak-like appearance, with a brown color and prominent texture, which made the material very suitable for decoration.

However, the brown color of uncoated thermally modified wood is not stable during long-term weathering, mainly because of photodegradation (Jämsä et al. 2000; Nuopponen et al. 2004; Huang et al. 2012; Yildiz et al. 2013). Ultraviolet (UV) light is considered the primary cause of the weathering and discoloration of wood. Among the main components of wood, lignin contributes $80 \%$ to $95 \%$ of the total UV absorption coefficient of wood, while carbohydrates contribute $5 \%$ to $20 \%$, and extractives contribute approximately $2 \%$ (Norrström 1969). The degradation begins with the absorption of UV light by $\alpha$-carbonyl, biphenyl, and ring-conjugated double bond structures in lignin (Lin and Kringstad 1970). The absorption of light by lignin leads to the formation of radical species with long lifetimes, whose subsequent radical reactions cause the wood color changes. Some studies have shown that the color stability of heat-treated wood is better than that of untreated wood due to chemical changes in the lignin, such as an increase in the lignin percentage or the formation of phenolic compounds in the heat-treatment process (Ayadi et al. 2003). Yildiz et al. (2011) reported that heat treatments delayed and decreased the rate of color change caused by weathering factors but did not completely prevent color change. However, according to Srinivas and Pandey (2012), thermal modification of wood does not induce resistance against UV light.

The present study was performed to examine the color changes in heat-treated rubber wood during photodegradation and to evaluate whether chemical changes during thermal modification improve the resistance of the wood against photodegradation. For this purpose, the color changes on exposed wood surfaces were analyzed using a colorimeter, and the chemical changes were monitored by Fourier-transform infrared spectroscopy (FTIR).

\section{EXPERIMENTAL}

\section{Materials}

Five 28-year-old rubber trees (Hevea brasiliensis), clone 7-33-97, were felled from an experimental field of the Chinese Academy of Tropical Agricultural Sciences, Hainan Province, China. The trunks were obtained from approximately $1.3 \mathrm{~m}$ above the ground and sawed into logs with a length of $1.2 \mathrm{~m}$. Quarter-sawed boards with dimensions of 1100 $\mathrm{mm}$ (longitudinal) $\times 110 \mathrm{~mm}($ radial $) \times 26 \mathrm{~mm}$ (tangential) were cut from the logs and then kiln-dried at $60{ }^{\circ} \mathrm{C}$ to prevent molding.

\section{Thermal Modification}

Nine quarter-sawed boards were piled in the middle of a heat-treatment kiln with a capacity of $0.3 \mathrm{~m}^{3}$, and the remaining space of the kiln was piled up with rubber wood boards with approximately the same dimensions, to fill the treatment kiln. The treatment started at an initial temperature of $55^{\circ} \mathrm{C}$, and the temperature was increased to $130{ }^{\circ} \mathrm{C}$ with an increase of $5^{\circ} \mathrm{C}$ every hour. Then, the temperature was increased to $155^{\circ} \mathrm{C}$, to $185^{\circ} \mathrm{C}$, and to $215{ }^{\circ} \mathrm{C}$ with increases of $10{ }^{\circ} \mathrm{C}$ every hour and maintained for a set period. Meanwhile, steam was continuously introduced into the kiln as a shielding gas when the temperature reached $130{ }^{\circ} \mathrm{C}$. Five treatment conditions were selected for parallel testing: treatment at $155{ }^{\circ} \mathrm{C}$ for $2 \mathrm{~h}$ and $6 \mathrm{~h}$ (hereinafter referred to as 155-2 and 155-6, 
respectively), treatment at $185^{\circ} \mathrm{C}$ for $2 \mathrm{~h}$ and $6 \mathrm{~h}$ (hereinafter referred to as 185-2 and 1856 , respectively), and treatment at $215^{\circ} \mathrm{C}$ for $2 \mathrm{~h}$ (hereinafter referred to as 215-2). The heattreated boards were placed in an indoor environment for 3 months to equilibrate their conditions.

Six rubber wood samples of size $50 \mathrm{~mm}$ (longitudinal) $\times 50 \mathrm{~mm}$ (radial) $\times 20 \mathrm{~mm}$ (tangential) were prepared for evaluation of weight loss (WL). The weight loss after thermal modification was calculated according to Eq.1,

$$
\mathrm{WL}=\left(W_{0}-W_{1}\right) / W_{0} \times 100 \%
$$

where $W_{0}$ and $W_{1}$ represent the oven-dry mass of the wood specimens before and after thermal modification, respectively.

\section{Preparation of Specimens}

Test specimens with sizes of $60 \mathrm{~mm}$ (longitudinal) $\times 20 \mathrm{~mm}$ (radial) $\times 5 \mathrm{~mm}$ (tangential) were cut from the sapwood portions of the thermally modified rubber wood boards, and untreated rubber wood boards were regarded as a control (hereinafter referred to as CK). The radial sections were used for the color and FTIR analyses.

\section{Accelerated UV Aging}

Twenty specimens of each treatment condition were exposed to UV light from UVA-340 lamps with a radiation intensity of $0.89 \mathrm{~W} / \mathrm{m}^{2}$ at room temperature. The irradiation was interrupted after 1 h, 2 h, 4 h, 8 h, 16 h, 24 h, 48 h, 96 h, 144 h, 192 h, 288 $\mathrm{h}$, and $384 \mathrm{~h}$ of treatment, to test the color changes caused by the UV light irradiation.

Another thirty-six specimens of each treatment condition were exposed to the same light conditions, and six pieces were taken out after 2 h, 8 h, 24 h, 96 h, 192 h, and $384 \mathrm{~h}$ of irradiation for FTIR analysis.

\section{Color Measurement}

The color changes resulting from the UV light irradiation were monitored using a colorimeter with a $10^{\circ}$ standard observer and D65 standard illuminant (SC-80C, Kangguang Optical Instrument Co., Ltd., Beijing, China) before and after exposure to light using the CIE $L^{*} a^{*} b^{*}$ color space. In the CIE $L^{*} a^{*} b^{*}$ system, the parameters $L^{*}, a^{*}$, and $b^{*}$ were measured, where $L^{*}$ represents the lightness, varying from 100 (white) to 0 (black), $a^{*}$ represents the red (+) to green (-) chromaticity coordinates, and $b^{*}$ represents the yellow $(+)$ to blue $(-)$ chromaticity coordinates. The total color change $\left(\Delta E^{*}\right)$, was computed using Eq. 2,

$$
\Delta E^{*}=\left[\left(\Delta L^{*}\right)^{2}+\left(\Delta a^{*}\right)^{2}+\left(\Delta b^{*}\right)^{2}\right]^{1 / 2}
$$

where $\Delta L^{*}, \Delta a^{*}$, and $\Delta b^{*}$, are the changes between the unirradiated and irradiated samples.

The center position of the specimens was taken as the measurement point, and each test piece was measured three times to obtain an average value.

\section{FTIR Analysis}

The FTIR spectra of the unirradiated and irradiated samples were measured using an FTIR spectrometer (Tensor-27, Bruker, Karlsruhe, Germany). The specimens were dried at $103{ }^{\circ} \mathrm{C}$ for $24 \mathrm{~h}$ in an oven before testing and then cooled. Powder samples were obtained by scraping the top layer of the irradiated surface of the specimens using a sharp blade and were then mixed with $\mathrm{KBr}$ in a weight ratio of 1:100 to form a pellet. The FTIR 
spectra were collected from $4000 \mathrm{~cm}^{-1}$ to $400 \mathrm{~cm}^{-1}$ at a spectral resolution of $4 \mathrm{~cm}^{-1}$.

\section{RESULTS AND DISCUSSION}

\section{Color Changes}

The color of heat-treated rubber wood changed according to different treatment conditions. Higher temperatures and longer treatment times caused greater declines in $L^{*}$. The reduction of $L^{*}$ value approximately linearly related to WL. And the most significant decrease in $L^{*}$ occurred in specimens treated at $215^{\circ} \mathrm{C}$ for $2 \mathrm{~h}$, a decrease of nearly $50 \%$ compared with the untreated samples. The values of $a^{*}$ and $b^{*}$ increased at the beginning of the treatment, and both declined after reaching a maximum, which agreed with previous studies (Bekhta and Niemz 2003; Brischke et al. 2007; González-Peña and Hale 2009). The maximum in $a^{*}$ was 14.85 (185-2) and in $b^{*}$ was 25.60 (155-6). At the most severe treatment (215-2), the $a^{*}$ value was still increased compared with untreated specimens, while the $b^{*}$ value was decreased. The colors of the rubber wood samples changed from light yellowish-white to dark brown as the treatment conditions became severe, which was because complex chemical reactions occurred at high temperature, causing the degradation of amorphous carbohydrate and the condensation of lignin (Sundqvist 2004; Esteves and Pereira 2009).

Table 1. WL and Color Parameters of Thermally Modified Rubber Wood Samples

\begin{tabular}{|c|c|c|c|c|}
\hline Sample & WL & $L^{*}$ & $a^{*}$ & $b^{*}$ \\
\hline CK & - & 72.90 & 7.05 & 20.27 \\
\hline $155-2$ & $0.55 \%$ & 69.19 & 11.77 & 24.54 \\
\hline $155-6$ & $1.21 \%$ & 62.28 & 10.75 & 25.60 \\
\hline $185-2$ & $2.58 \%$ & 55.58 & 14.85 & 25.07 \\
\hline $185-6$ & $4.68 \%$ & 47.25 & 12.91 & 24.29 \\
\hline $215-2$ & $11.66 \%$ & 36.59 & 11.67 & 15.76 \\
\hline
\end{tabular}

As shown in Fig. 1, samples (untreated specimens, 155-2, 155-6, and 185-2) having an initial $L^{*}$ value greater than 50 showed rapid decreasing lightness during the beginning period of UV exposure.

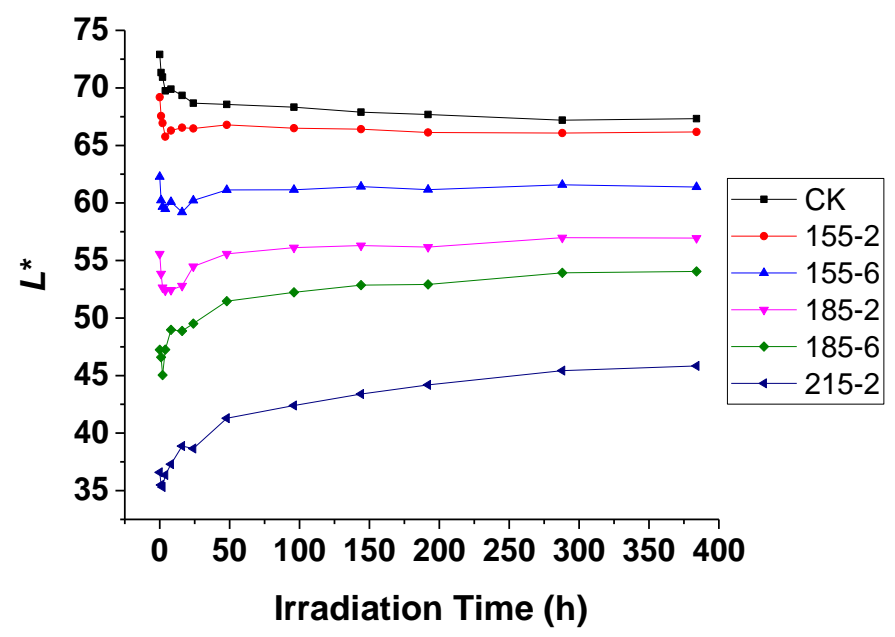

Fig. 1. Variation in the lightness parameter $L^{*}$ in the UV aging test 
For untreated samples, the rapid decline period lasted for $48 \mathrm{~h}$, then the decrease was slight, and for samples treated at $155^{\circ} \mathrm{C}$ for $2 \mathrm{~h}$ and $6 \mathrm{~h}$, and $185^{\circ} \mathrm{C}$ for $2 \mathrm{~h}$, the rapid declining period ended in the first $24 \mathrm{~h}$, then increased or stabilized. Wood materials under photo-irradiation become generally darkened, as was observed for untreated rubber wood in the present study, and this is commonly attributed to the degradation of lignin and other non-cellulosic polysaccharides (Hon and Chang 1985; Grelier et al. 2000; Petric et al. 2004). Compared to the reports by Pandey (2005a), the monotonous decrease of $L^{*}$ value in untreated rubber wood was just like extractive-free wood, rooted in the absence of colored extractives probably. The reversal of $L^{*}$ value in mildly treated samples (155-2, 155-6, and 185-2) was just like unextracted wood, rooted in the chromophore groups produced in heat treatment. Samples (185-6 and 215-2) having an initial $L^{*}$ value less than 50 showed rapid increasing lightness during the beginning $48 \mathrm{~h}$ of photoaging and then increased slowly, similar to those of wood species abundant in extractives might become bleached before the browning.

The parameter $a^{*}$ of the untreated rubber wood increased steeply during the initial $24 \mathrm{~h}$ of photoaging and increased continuously in the following aging process. For samples treated at $155^{\circ} \mathrm{C}$ for $2 \mathrm{~h}$ and $6 \mathrm{~h}$, and at $185^{\circ} \mathrm{C}$ for $2 \mathrm{~h}$, the $a^{*}$ values increased in varying degrees in the initial period of aging. After $96 \mathrm{~h}$ of photoaging, the $a^{*}$ values of these three groups of samples $(155-2,155-6$, and 185-2) were remarkably close to that of the untreated rubber wood. The color parameter $a^{*}$ of the rubber wood treated at $185^{\circ} \mathrm{C}$ for $6 \mathrm{~h}$ and 215 ${ }^{\circ} \mathrm{C}$ for $2 \mathrm{~h}$ remained mostly stable throughout the aging process.

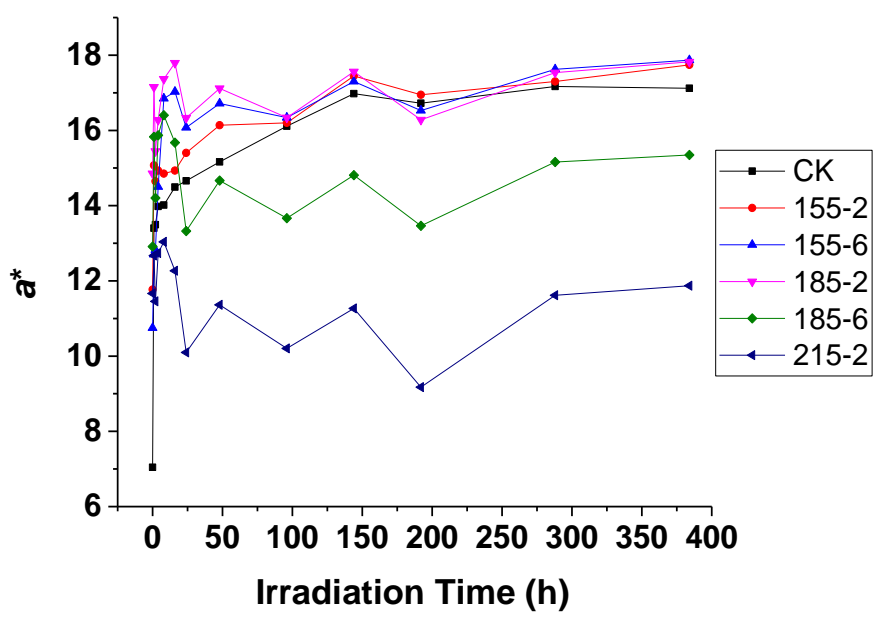

Fig. 2. Variation in the red-green parameter $a^{*}$ in the UV aging test

The $b^{*}$ value of the untreated rubber wood continued to increase and then became stable after aging for $96 \mathrm{~h}$. Notable increases in the parameter $b^{*}$ could be detected in the beginning $24 \mathrm{~h}$ of aging in the samples treated at $155^{\circ} \mathrm{C}$ for $2 \mathrm{~h}$ and $6 \mathrm{~h}$ and at $185^{\circ} \mathrm{C}$ for $2 \mathrm{~h}$. After $96 \mathrm{~h}$ aging, the $b^{*}$ values of untreated specimens and specimens treated at mild conditions (155-2, 155-6, and 185-2), which experienced increases to different degrees, were remarkably close to each other. The $b^{*}$ values of samples treated at $185{ }^{\circ} \mathrm{C}$ for $6 \mathrm{~h}$ and $215^{\circ} \mathrm{C}$ for $2 \mathrm{~h}$ showed increases during the initial $24 \mathrm{~h}$ of the aging test, but to a relatively smaller extent than the other samples. 


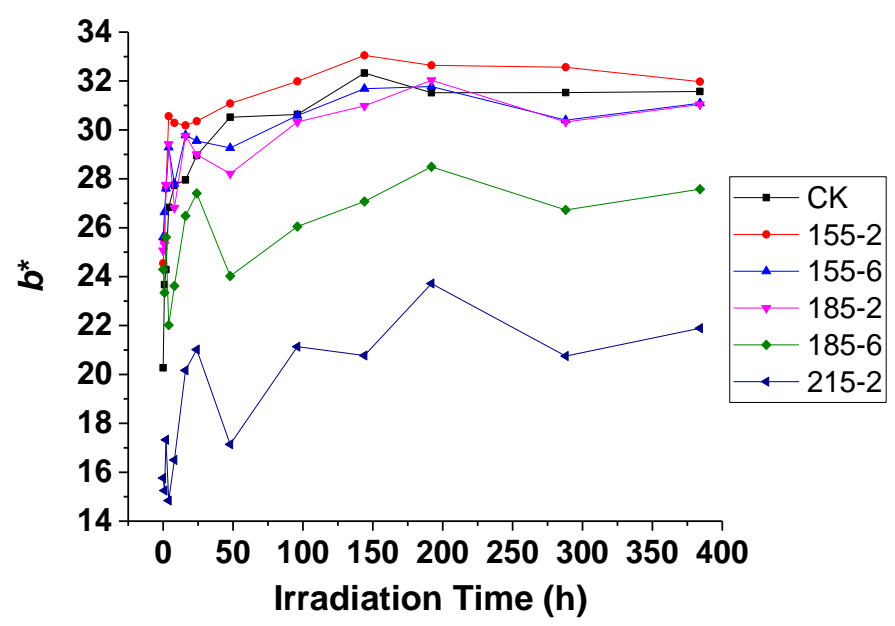

Fig. 3. Variation in the yellow-blue parameter $b^{*}$ in the UV aging test

The total color difference $\left(\Delta E^{*}\right)$ of each group increased steadily as the irradiation time increased, and the enormous changes occurred during the first $4 \mathrm{~h}$ of the aging process. The color changes in the untreated rubber wood during the phase from $4 \mathrm{~h}$ to $48 \mathrm{~h}$ were rapid but slowed after that. For the heat-treated rubber wood, the color changes became more moderate after $48 \mathrm{~h}$ of aging. The $\Delta E^{*}$ value of the untreated rubber wood was considerably greater than that of each group of the heat-modified materials.

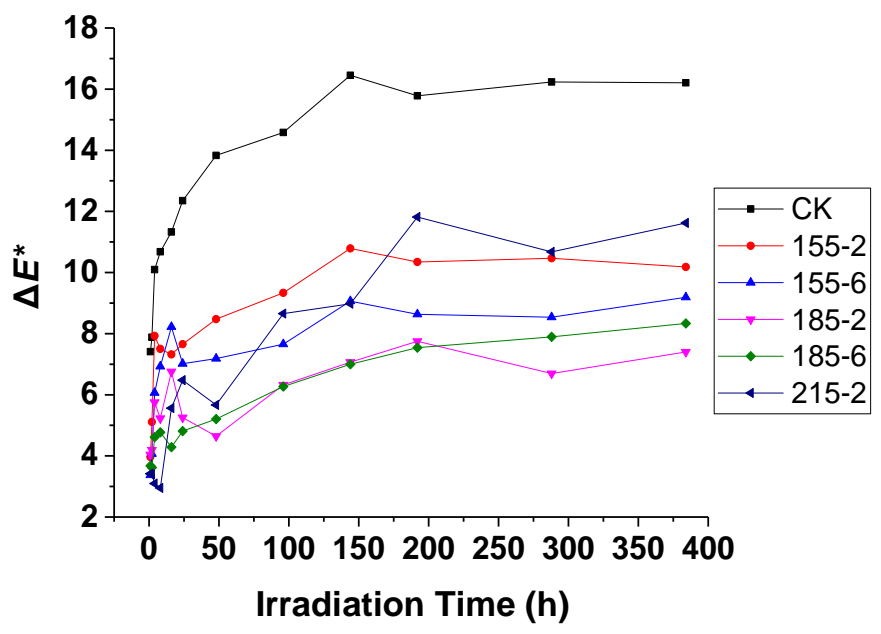

Fig. 4. Variation in the total color change $\Delta E^{*}$ in the UV aging test

Table 2. Changes in Color Parameters after $384 \mathrm{~h}$ of Irradiation

\begin{tabular}{|c|c|c|c|c|}
\hline Sample & $\Delta E^{*}$ & $\Delta L^{*}$ & $\Delta a^{*}$ & $\Delta b^{*}$ \\
\hline CK & 16.21 & -5.57 & 10.07 & 11.30 \\
\hline $155-2$ & 10.18 & -3.01 & 5.97 & 7.43 \\
\hline $155-6$ & 9.19 & -0.89 & 7.12 & 5.49 \\
\hline $185-2$ & 7.40 & 1.37 & 2.97 & 5.98 \\
\hline $185-6$ & 8.33 & 6.81 & 2.43 & 3.28 \\
\hline $215-2$ & 11.62 & 9.24 & 0.21 & 6.13 \\
\hline
\end{tabular}



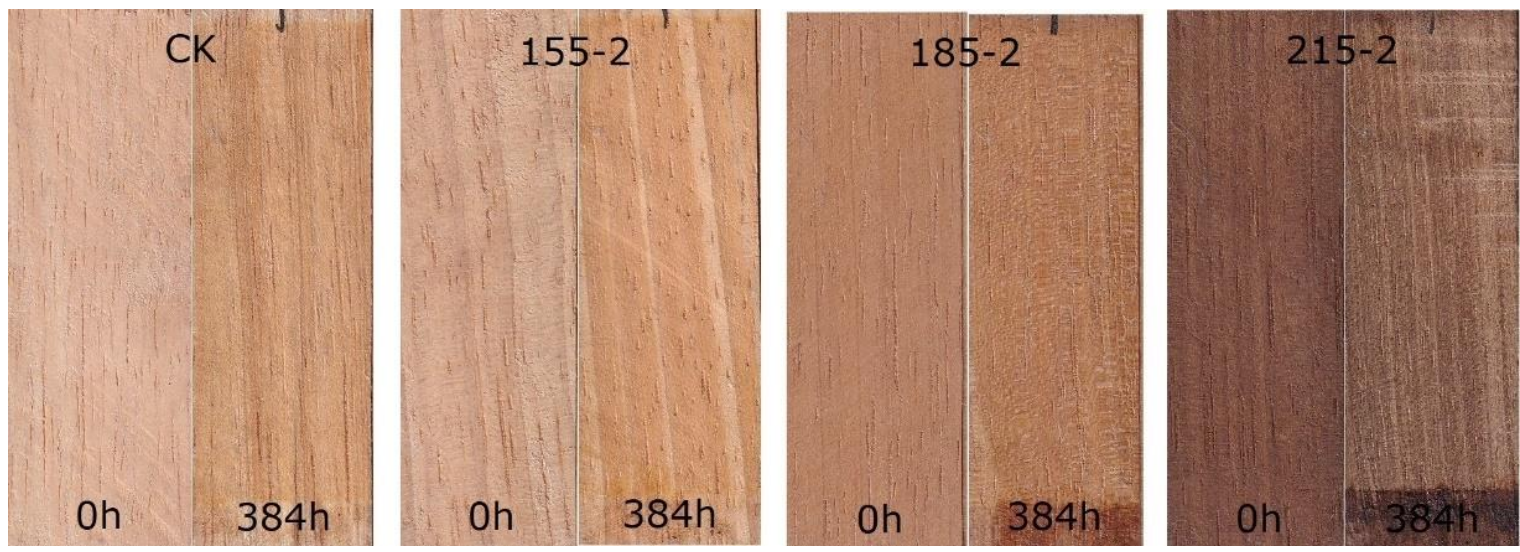

Fig. 5. Photographs of untreated specimens and specimens treated at $155^{\circ} \mathrm{C}$ for $2 \mathrm{~h}, 185^{\circ} \mathrm{C}$ for $2 \mathrm{~h}$, and $215^{\circ} \mathrm{C}$ for $2 \mathrm{~h}$ before and after $384 \mathrm{~h}$ irradiated process

The changes in the color parameters $L^{*}, a^{*}$, and $b^{*}$ and total color difference $\left(\Delta E^{*}\right)$ at the end of the aging process are shown in Table 2. The photographs of untreated specimens and specimens treated at $155^{\circ} \mathrm{C}$ for $2 \mathrm{~h}, 185^{\circ} \mathrm{C}$ for $2 \mathrm{~h}$, and $215^{\circ} \mathrm{C}$ for $2 \mathrm{~h}$ before and after $384 \mathrm{~h}$ irradiation, which were recorded on a Canon Lide-110 scanner, are shown in Fig. 5. After $384 \mathrm{~h}$ of aging, $L^{*}$ values of untreated samples and samples treated at $155^{\circ} \mathrm{C}$ for $2 \mathrm{~h}$ and $6 \mathrm{~h}$ decreased, while $L^{*}$ values of samples treated at $185^{\circ} \mathrm{C}$ for $2 \mathrm{~h}$ and $6 \mathrm{~h}$ and $215^{\circ} \mathrm{C}$ for $2 \mathrm{~h}$ increased. Parameters $a^{*}$ and $b^{*}$ of all samples increased, which might be due to the photo-oxidation of lignin generating new chromophore groups such as quinone leading to the increasing of $a^{*}$ and $b^{*}$. Though samples treated at severe conditions (185-6 and 215-2) had lower increment of $a^{*}$ and $b^{*}$, the greater $\Delta L^{*}$ value resulted in higher total color difference $\left(\Delta E^{*}\right)$. The rubber wood treated at $185^{\circ} \mathrm{C}$ for $2 \mathrm{~h}$, which had lower values of $\Delta L^{*}, \Delta a^{*}$, and $\Delta b^{*}$, had the lowest $\Delta E^{*}$ value. It has been reported (Srinivas and Pandey 2012) that thermally modified rubber wood presents a greater $\Delta E^{*}$ value than untreated wood, in which study rubber wood specimens were treated at $225^{\circ} \mathrm{C}$, obtaining a much darker appearance with a pretty low $L^{*}$ value, that would increase significantly under irradiation and produced a greater $\Delta E^{*}$ than untreated rubber wood.

Severo et al. (2016) reported that only hemicellulose was partially degraded when rubber wood treated at $180{ }^{\circ} \mathrm{C}$, and the contents of lignin and extractives increased when treated at $200{ }^{\circ} \mathrm{C}$ or above. Therefore, it can be inferred that rubber wood treated at 155 ${ }^{\circ} \mathrm{C}$, and treated at $185^{\circ} \mathrm{C}$ for $2 \mathrm{~h}$, had a very slight modification, which was consistent with the low WL. And the mild treated rubber wood showed a similar performance with untreated rubber wood under UV irradiation in an alleviated intensity. For the rubber wood treated at severe conditions (185-6 and 215-2), amorphous carbohydrates were deeply degraded in the thermal modification process, associated with the generation of colorful extractives (Esteves et al. 2008b; Ahajji et al. 2009), and chromophore groups were also produced from the condensation of lignin (González-Peña and Hale 2009). These chromophoric species, which gave the severely modified rubber wood a much darker color than untreated wood, degraded substantially under UV light, leading to a dramatic increase of $L^{*}$ value. It is implied that the color stability of rubber wood is improved when samples are treated under mild conditions and weakened when samples are treated under severe conditions. 


\section{FTIR Analysis}

The differences in spectra between the heat-treated and untreated rubber wood were difficult to interpret because several reactions were occurring at the same time; nevertheless, several changes were observed (Fig. 6). The band located at approximately $1737 \mathrm{~cm}^{-1}$ shifted to smaller wavenumbers, which might be due to the breaking of acetyl or acetoxy groups in xylan, according to Tjeerdsma and Militz (2005) and Kocaefe et al. (2008).

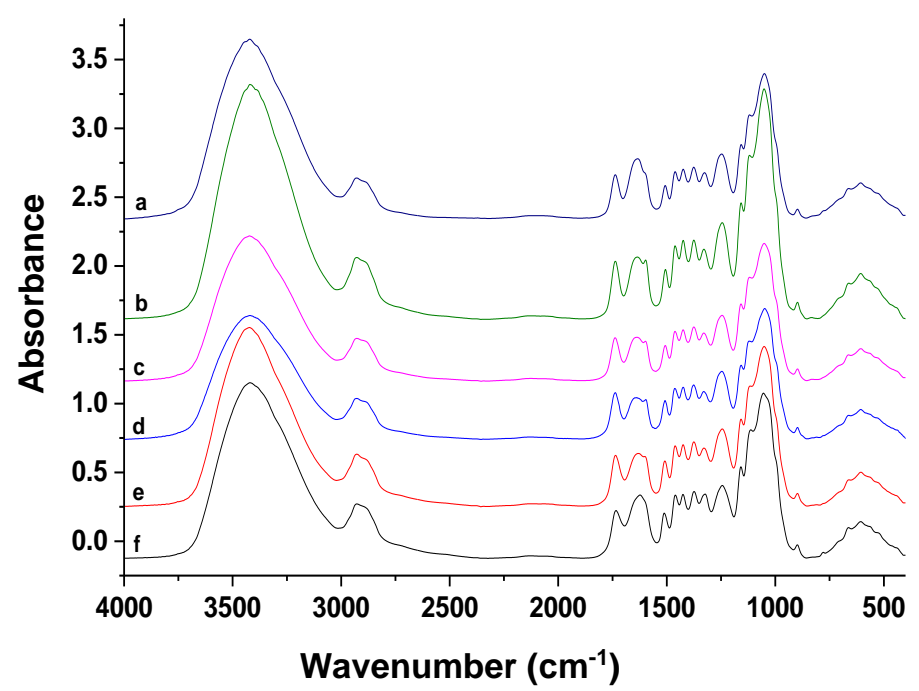

Fig. 6. FTIR spectra of thermally treated and untreated rubber wood: (a) untreated, (b) $155^{\circ} \mathrm{C}$ for $2 \mathrm{~h}$, (c) $155^{\circ} \mathrm{C}$ for $6 \mathrm{~h}$, (d) $185^{\circ} \mathrm{C}$ for $2 \mathrm{~h}$, (e) $185^{\circ} \mathrm{C}$ for $6 \mathrm{~h}$, (f) $215^{\circ} \mathrm{C}$ for $2 \mathrm{~h}$

Another change occurred between $1600 \mathrm{~cm}^{-1}$ and $1650 \mathrm{~cm}^{-1}$. In specimens treated at $155^{\circ} \mathrm{C}$ for $2 \mathrm{~h}$ and $6 \mathrm{~h}$ and at $185^{\circ} \mathrm{C}$ for $2 \mathrm{~h}$, the spectrum split into a double peak as the absorbance at $1596 \mathrm{~cm}^{-1}$ increased. The band at $1596 \mathrm{~cm}^{-1}$ arises from aromatic skeletal vibrations plus $\mathrm{C}=\mathrm{O}$ stretching (Sarkanen et al. 1967; Hergert 1971; Faix 1992). As the aromatic ring of lignin can hardly react when treated at mild conditions (155-2, 155-6, and 185-2), it was more likely that some of the reactive sites might have undergone oxidation reaction at heat treatment, and led to formation of carbonyl groups. Because in the thermal modification process, there was a trace amount of oxygen in medium, coming from air and dissolved oxygen in water used to generate vapor. Reasonable speculation is that quinone compounds had been formed, since quinones are common products of phenol oxidation and have two peaks at around 1680 and $1600 \mathrm{~cm}^{-1}$. That was also compatible with the increase of color parameters $a^{*}$ and $b^{*}$ since quinones can cause an intense color at very low concentrations (Tolvaj and Faix 1995). The peak at $1596 \mathrm{~cm}^{-1}$ was weakened or covered when the specimens treated at $185{ }^{\circ} \mathrm{C}$ for $6 \mathrm{~h}$ and at $215^{\circ} \mathrm{C}$ for $2 \mathrm{~h}$, and the absorption band originally located at $1633 \mathrm{~cm}^{-1}$ shifted to $1623 \mathrm{~cm}^{-1}$. In the more severe treatment, quinone compounds might further react, and the values of $a^{*}$ and $b^{*}$ decreased.

The band corresponding to benzene ring stretching vibrations (Faix 1991) shifted to high wavenumber as the treatment became more severe, from $1506 \mathrm{~cm}^{-1}$ (untreated, 155 2, and 155-6), to $1508 \mathrm{~cm}^{-1}$ (185-2 and 185-6) and finally to $1512 \mathrm{~cm}^{-1}$ (215-2). Previous studies show that thermal modification induces changes in the lignin structures mainly through cleavage of the $\beta-\mathrm{O}-4$ linkages, detachment of methoxy groups, and 
recondensation reactions forming 5, 5'-biphenolic and diarylmethane structures (Funaoka et al. 1990; Tjeerdsma et al. 1998; Brosse et al. 2010; Esteves et al. 2013). As a result, the molecules of lignin become more condensed and much darker (González-Peña and Hale 2009). Comparing the band shifting at 1633 and $1510 \mathrm{~cm}^{-1}$ when treated at varying degrees of heat treatment, it was reasonable to assume that such dramatic reactions mostly occurred at severe treatments (185-6 and 215-2).

Figures 7 to 12 show the FTIR spectra of the heat-treated and untreated rubber wood after UV irradiation for different periods.

In heat-treated and untreated samples, the bands at $1507 \mathrm{~cm}^{-1}, 1461 \mathrm{~cm}^{-1}$, and 1250 $\mathrm{cm}^{-1}$, which were assigned to lignin (Marchessault 1962; Harrington et al. 1964; Evans 1991; Faix 1991; Collier et al. 1992), decreased clearly after irradiation. Especially the absorption band at $1507 \mathrm{~cm}^{-1}$, which mainly attributes to aromatic skeletal vibrations, almost disappeared after aging for $384 \mathrm{~h}$, indicating degradation of lignin thoroughly. This result was accompanied by a simultaneous increase in the intensity of the band at $1737 \mathrm{~cm}^{-}$ ${ }^{1}$, which is assigned to unconjugated carbonyls (Faix 1992). The carbohydrate bands at $1375 \mathrm{~cm}^{-1}$ (Liang and Marchessault 1959), and $898 \mathrm{~cm}^{-1}$ (Higgins et al. 1961; Marchessault and Liang 1962) were not greatly influenced by UV irradiation on the heat-treated or untreated rubber wood surfaces. It is well known that lignin is the main component of light energy absorption. The excited electronic states formed in lignin after light absorption can generate reactive radical species, which in turn react with oxygen to form chromophores, such as quinone structures (Argyropoulos et al. 1995; Müller et al. 2003). In the present study, the reduction of bands attributed to lignin and the enhancement of band at $1737 \mathrm{~cm}^{-}$ ${ }^{1}$ can be attributed to non-conjugated carbonyls characterized the photodegradation of lignin and formation of oxidation products, which is consistent with the reported studies (Hon and Feist 1986; Tolvaj and Faix 1995; Colom et al. 2003; Pandey 2005b). Aromatic skeletal of lignin in heat-treated rubber wood photodegraded in a similar pattern as untreated rubber wood.

In untreated rubber wood, band at $1596 \mathrm{~cm}^{-1}$, a superimposed band that attributed to aromatic skeletal vibrations plus $\mathrm{C}=\mathrm{O}$ stretching, increased, and a new peak was formed. As mentioned before, the enhancement at band $1596 \mathrm{~cm}^{-1}$ was mostly caused by the formation of conjugated carbonyls, since lignin degraded under UV light. Quinone compounds were probably produced according to previous studies, causing the color parameters $a^{*}$ and $b^{*}$ to increase sharply during the beginning $24 \mathrm{~h}$ of UV irradiation. After $24 \mathrm{~h}$ irradiation, the absorbance at $1596 \mathrm{~cm}^{-1}$ was gradually weakened, which might be caused by the photodegradation of lignin and further oxidation of quinone structures (Muasher and Sain 2006); meanwhile the variations in $a^{*}$ and $b^{*}$ were greatly reduced compared to the beginning period. There was an absorption peak at $1596 \mathrm{~cm}^{-1}$ before irradiation in rubber wood samples treated at mild conditions (155-2, 155-6, and 185-2), which was similar to that of the untreated samples after short irradiation and was probably caused by the oxidation occurred in thermal modification as mentioned before. The 1596 $\mathrm{cm}^{-1}$ peak in mildly modified samples decreased in a similar pattern under irradiation like untreated samples, and values of their color parameters $a^{*}$ and $b^{*}$ were close to that of untreated samples after $24 \mathrm{~h}$ irradiation. Therefore, it was reasonable to assume that similar reactions occurred in those specimens. In contrast, samples treated at $185{ }^{\circ} \mathrm{C}$ for $6 \mathrm{~h}$ and $215^{\circ} \mathrm{C}$ for $2 \mathrm{~h}$ showed significant differences in band shapes from 1600 to $1650 \mathrm{~cm}^{-1}$. 


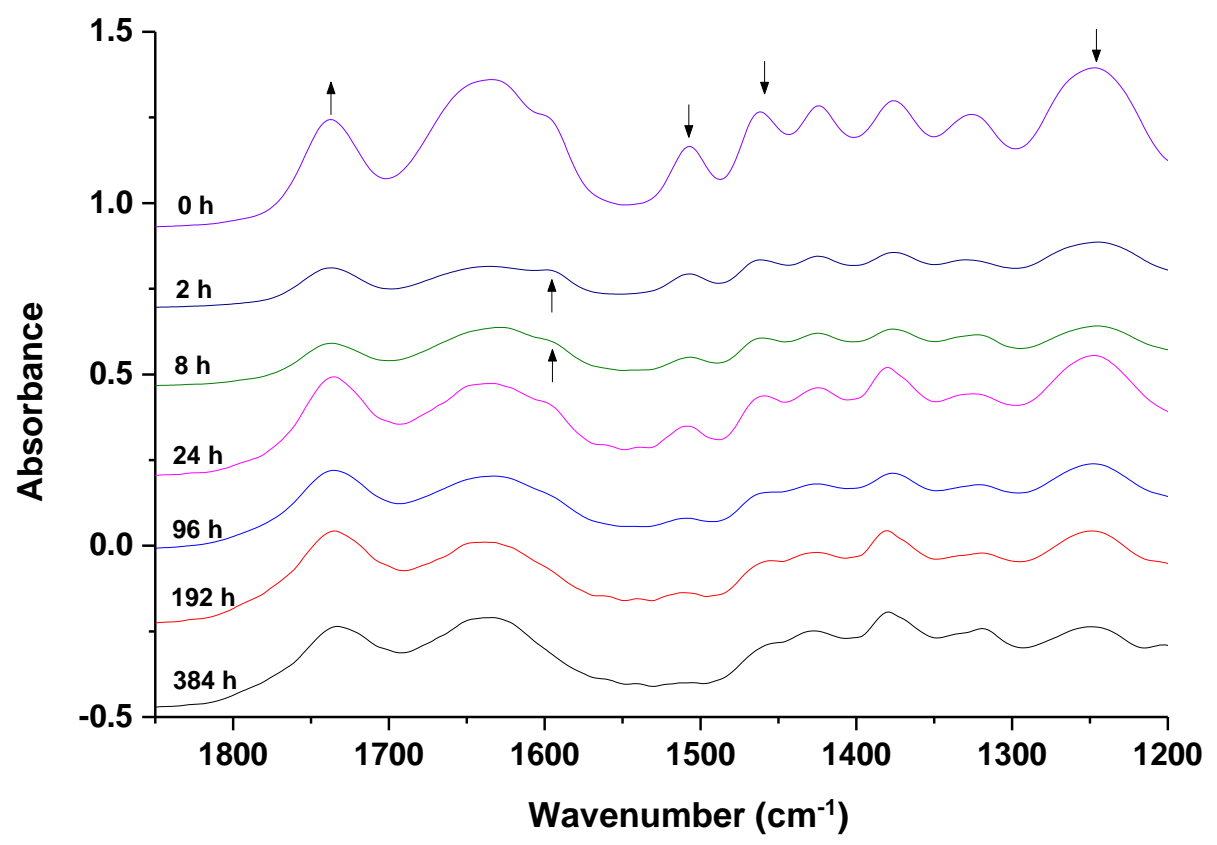

Fig. 7. FTIR spectra of untreated rubber wood aged in the UV aging test

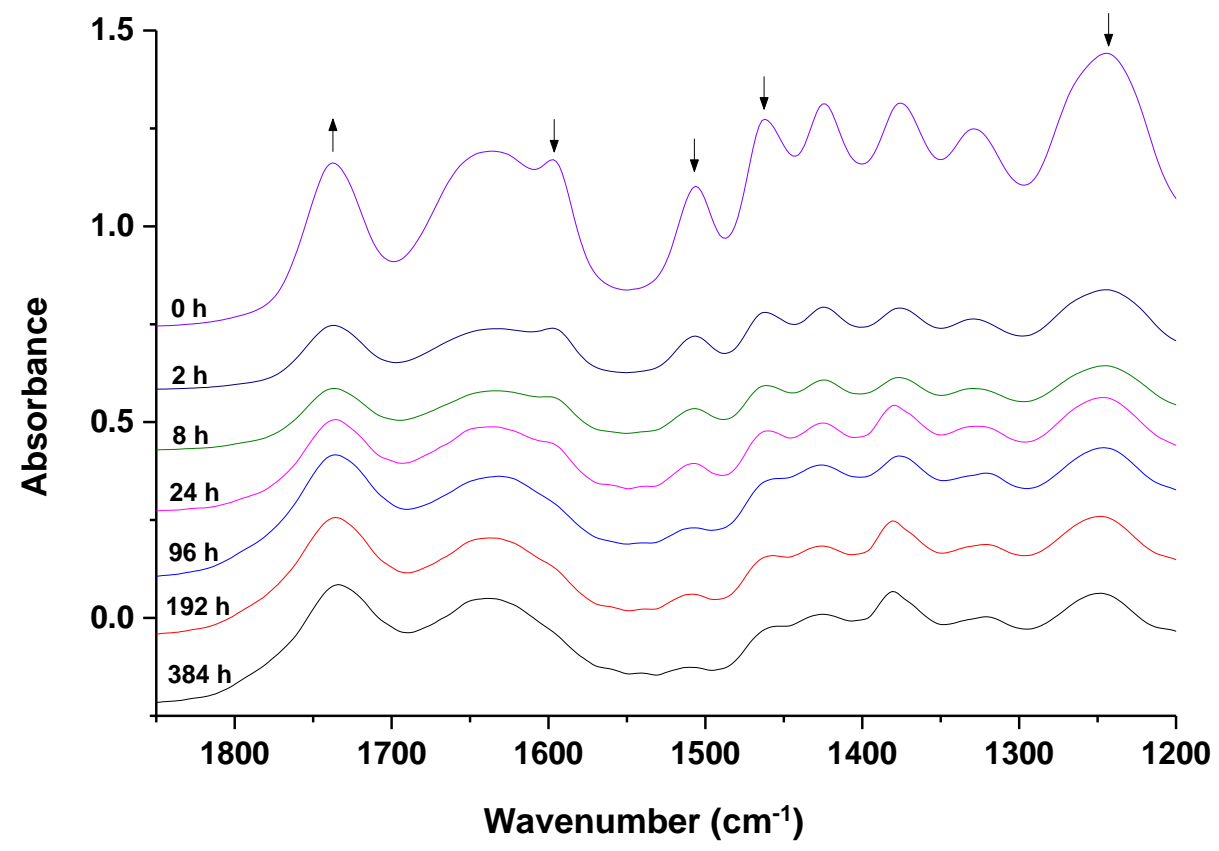

Fig. 8. FTIR spectra of rubber wood treated at $155^{\circ} \mathrm{C}$ for $2 \mathrm{~h}$ aged in the UV aging test 


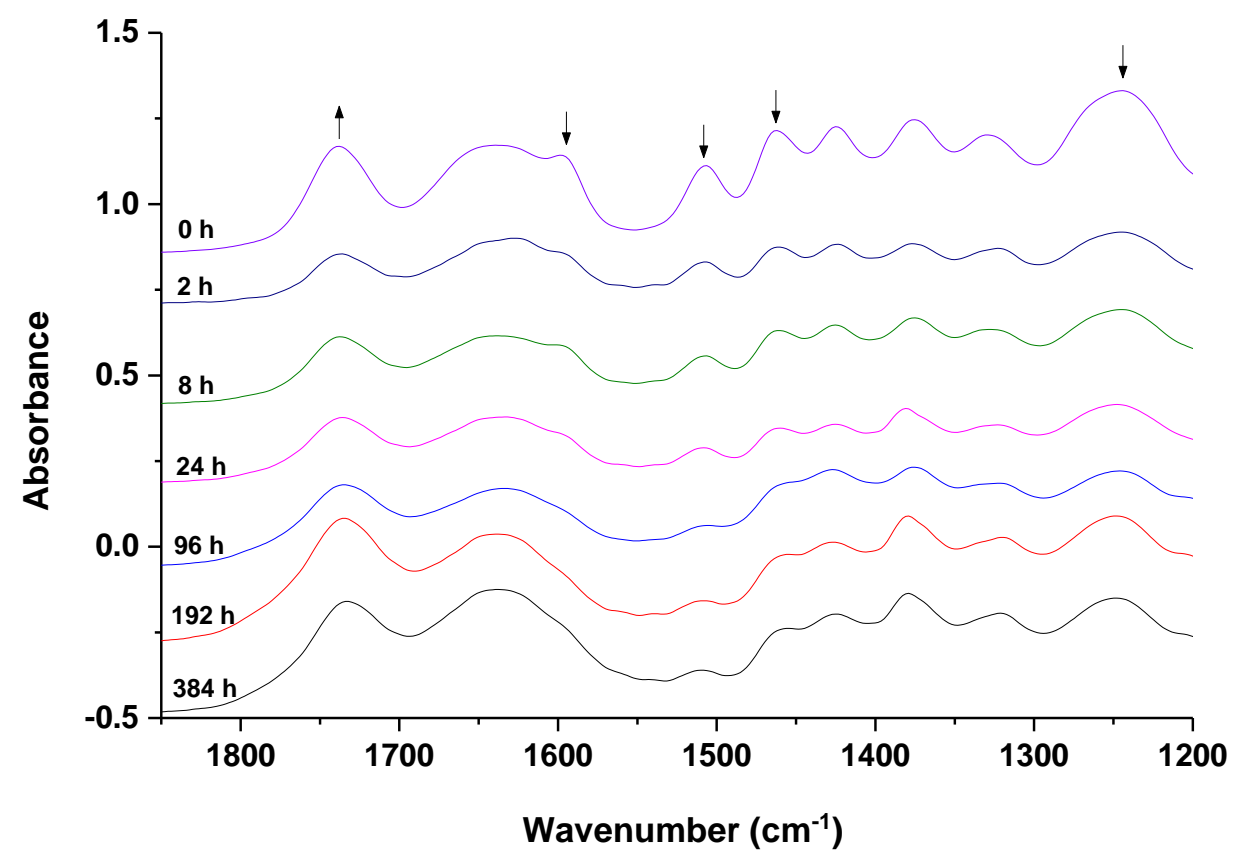

Fig. 9. FTIR spectra of rubber wood treated at $155^{\circ} \mathrm{C}$ for $6 \mathrm{~h}$ aged in the UV aging test

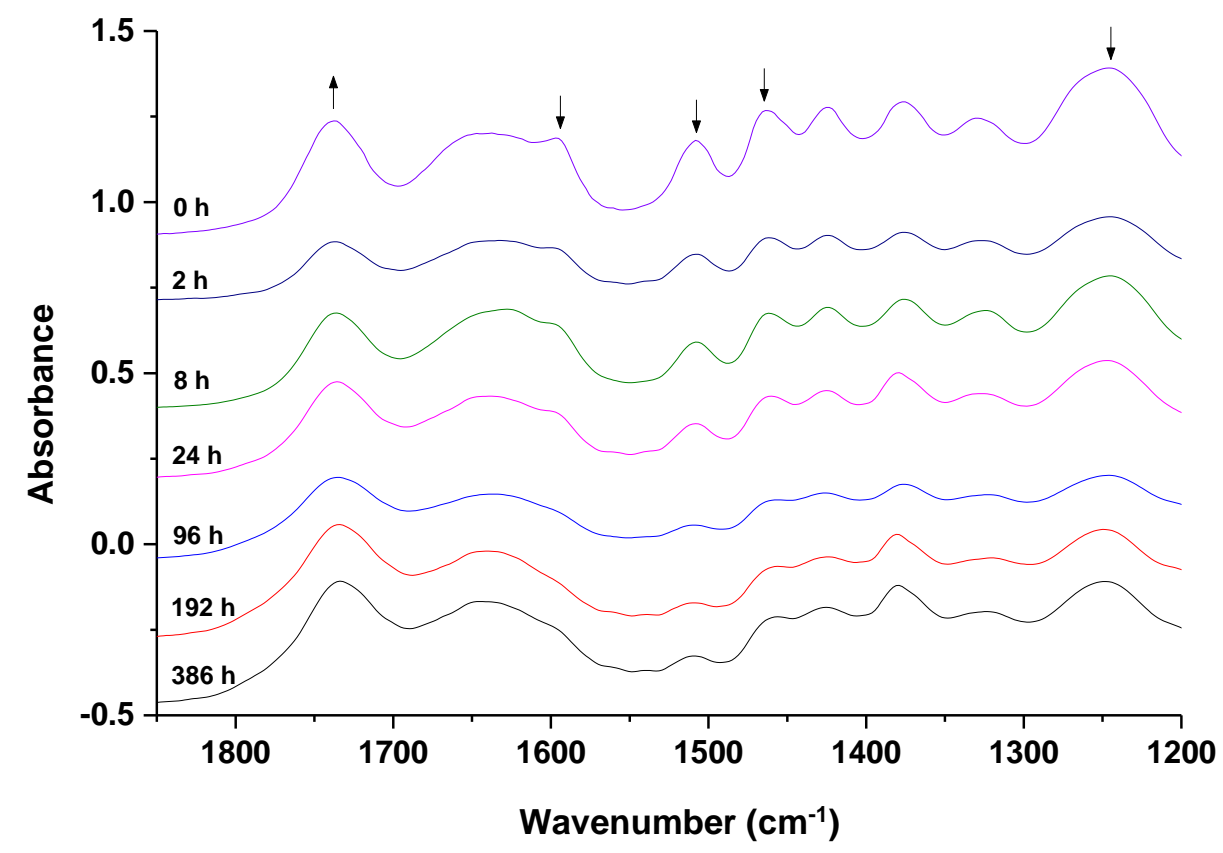

Fig. 10. FTIR spectra of rubber wood treated at $185^{\circ} \mathrm{C}$ for $2 \mathrm{~h}$ aged in the UV aging test 


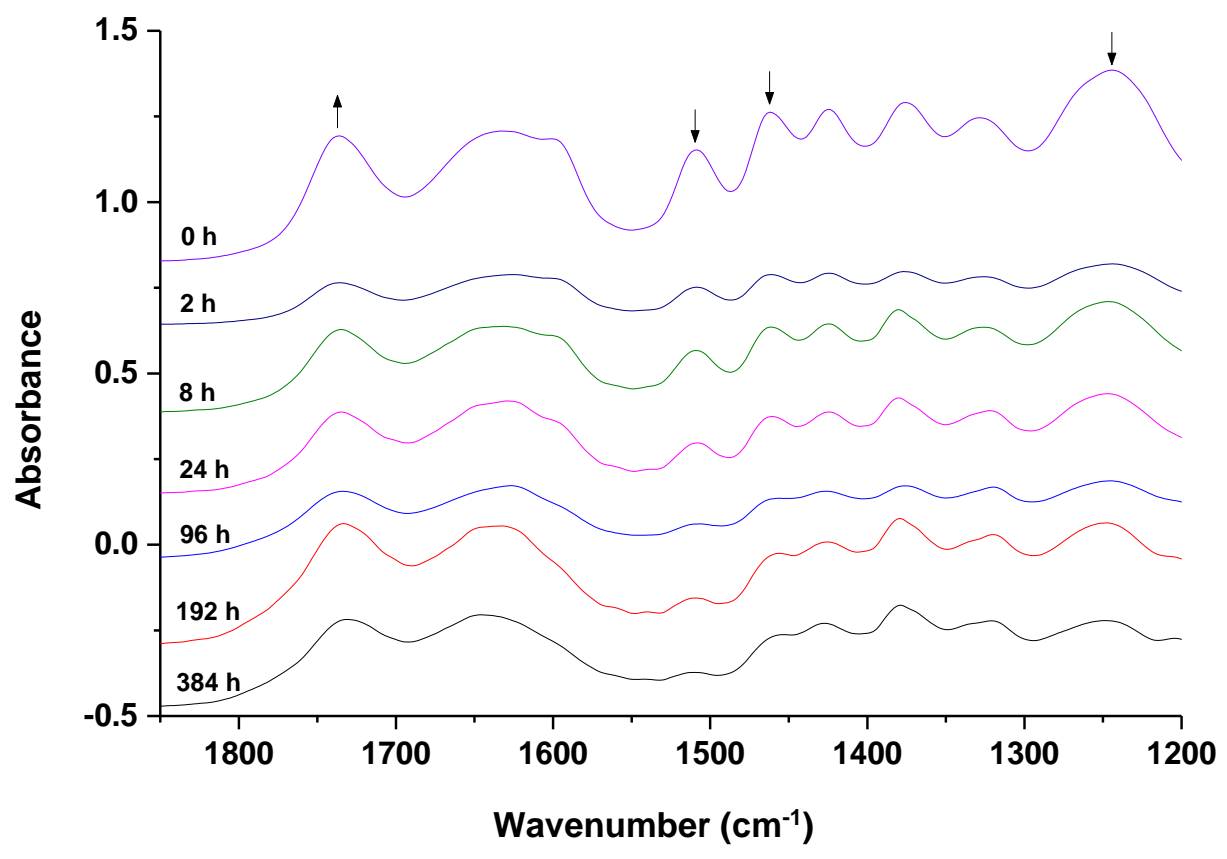

Fig. 11. FTIR spectra of rubber wood treated at $185^{\circ} \mathrm{C}$ for $6 \mathrm{~h}$ aged in the UV aging test

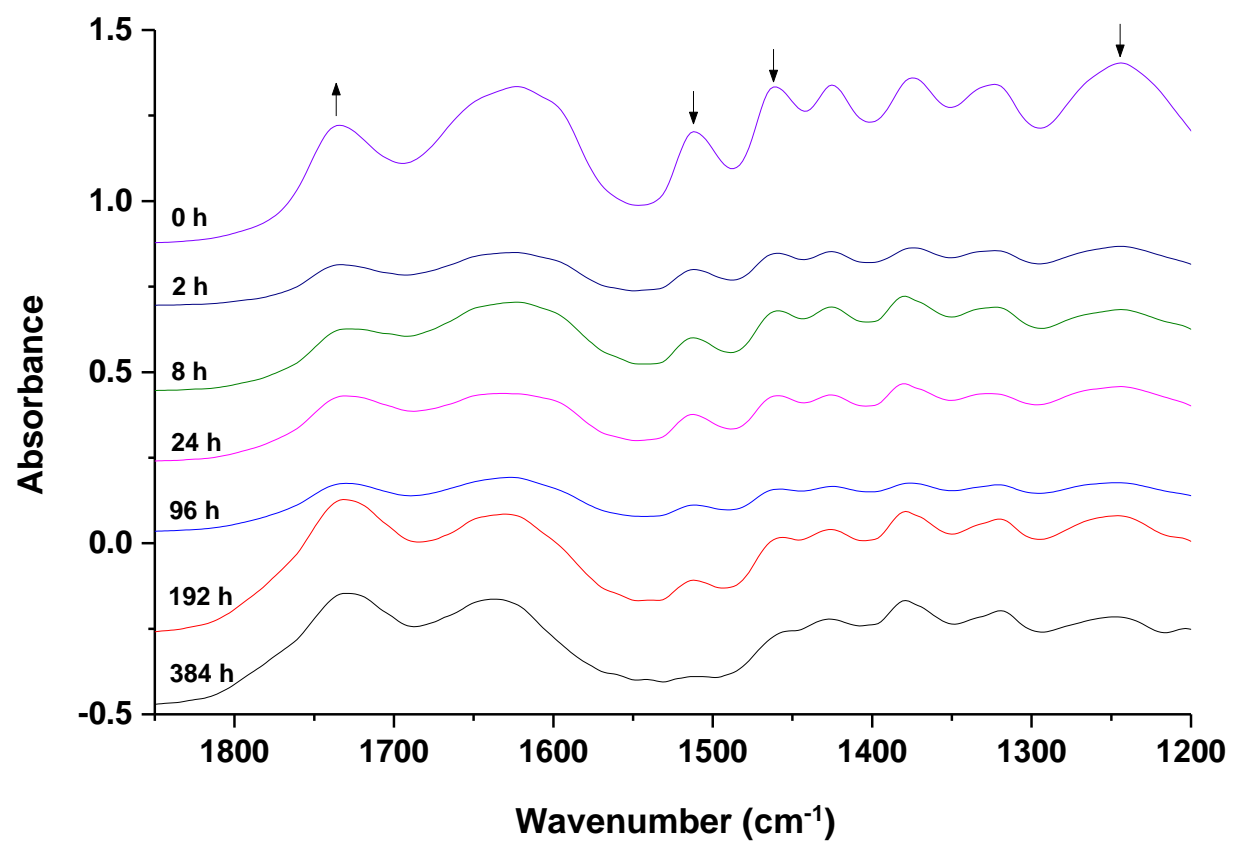

Fig. 12. FTIR spectra of rubber wood treated at $215^{\circ} \mathrm{C}$ for $2 \mathrm{~h}$ aged in the UV aging test

In order to investigate the details in photodegradation, the intensities of the carbonyl band located at $1737 \mathrm{~cm}^{-1}$, lignin band at $1510 \mathrm{~cm}^{-1}$, and carbohydrate reference band at $1375 \mathrm{~cm}^{-1}$ were measured as reported in the literature by Pandey (2005b). The variations in the $I_{1510} / I_{1375}$ ratio throughout the irradiation time are shown in Fig. 13 . The $I_{1507} / I_{1375}$ ratio decreased rapidly during the initial period of the aging test. The curves of specimens 
treated at $155{ }^{\circ} \mathrm{C}$ for $2 \mathrm{~h}$ and $6 \mathrm{~h}$ were very close to that of the untreated rubber wood, whereas the specimens treated at $185^{\circ} \mathrm{C}$ for $6 \mathrm{~h}$ and at $215^{\circ} \mathrm{C}$ for $2 \mathrm{~h}$ showed a slightly slower decline in the first $192 \mathrm{~h}$ of radiation. That might be due to the considerable number of extractives produced in severe modification (185-6 and 215-2), which had high antioxidant activities and hindered photodegradation of lignin (Ahajji et al. 2009; Shen et al. 2016).

To investigate the relationship between the photochemical reactions and color changes, the correlations between the total color difference $\Delta E^{*}$ and the rate of lignin degradation and between $\Delta E^{*}$ and the nonconjugated carbonyl group content were determined (Fig. 14). A high correlation between $\Delta E^{*}$ and lignin degradation $\left(I_{1507} / I_{1375}\right)$ was discovered, and the correlation coefficient $\mathrm{R}^{2}$ values of the untreated specimens and the specimens treated at $155^{\circ} \mathrm{C}$ for $2 \mathrm{~h}$ and $6 \mathrm{~h}$ and at $185^{\circ} \mathrm{C} 2 \mathrm{~h}$ and $6 \mathrm{~h}$ were 0.9448 , $0.9083,0.921,0.939$, and 0.8985 , respectively. The $\mathrm{R}^{2}$ value for $\Delta E^{*}$ and $I_{1507} / I_{1375}$ decreased to 0.6359 for the specimens treated at $215{ }^{\circ} \mathrm{C}$ for $2 \mathrm{~h}$, showing a diminished relation between color change and lignin degradation. It was concluded that fundamental changes were caused in the lignin of the rubber wood during heat treatment at $215{ }^{\circ} \mathrm{C}$ for $2 \mathrm{~h}$, compared to the specimens treated under other conditions or the untreated specimens, whose correlation performances were similar.

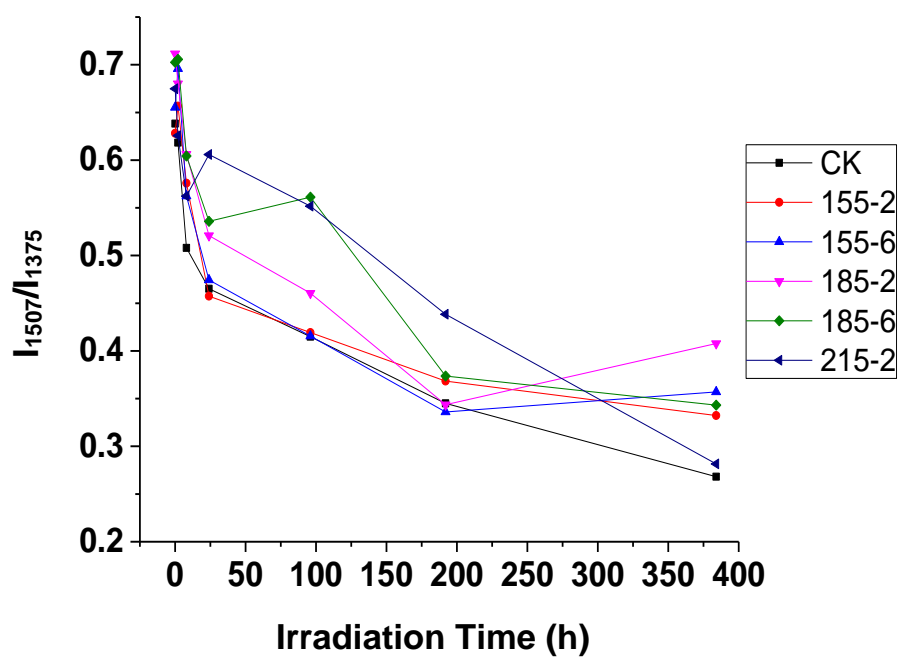

Fig. 13. Decay in lignin reference peak at $1507 \mathrm{~cm}^{-1}$ during the UV aging test

It has been suggested that the formation of nonconjugated carbonyl functionalities plays an important role in color changes in wood (Kishino and Nakano 2004). Pandey (2005b) also reported that the color changes ( $\Delta E^{*}$ values) in chir pine and rubber wood during irradiation were linearly correlated with the degradation of lignin and formation of nonconjugated carbonyl groups, as determined by FTIR measurements. Similar results were observed by Wang et al. (2009). 
a

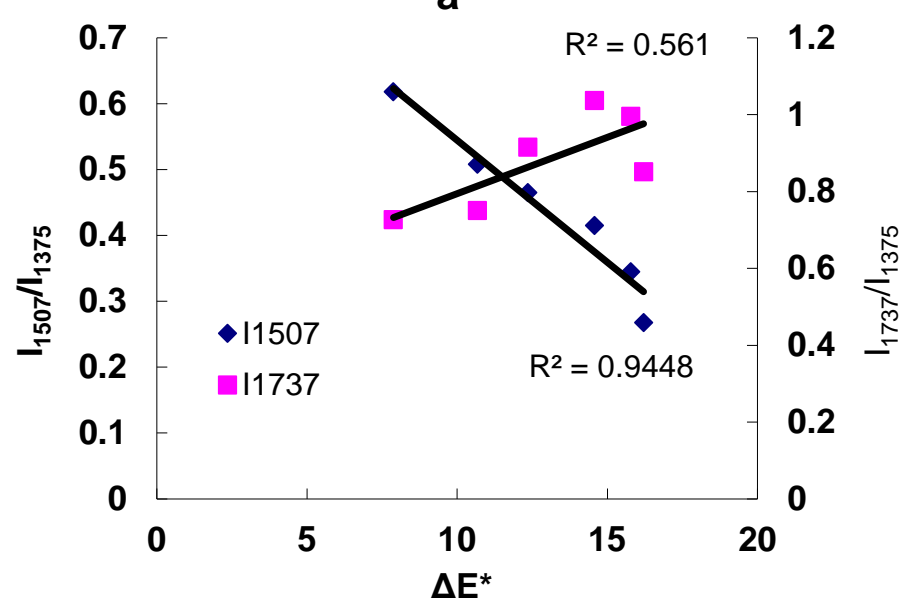

C
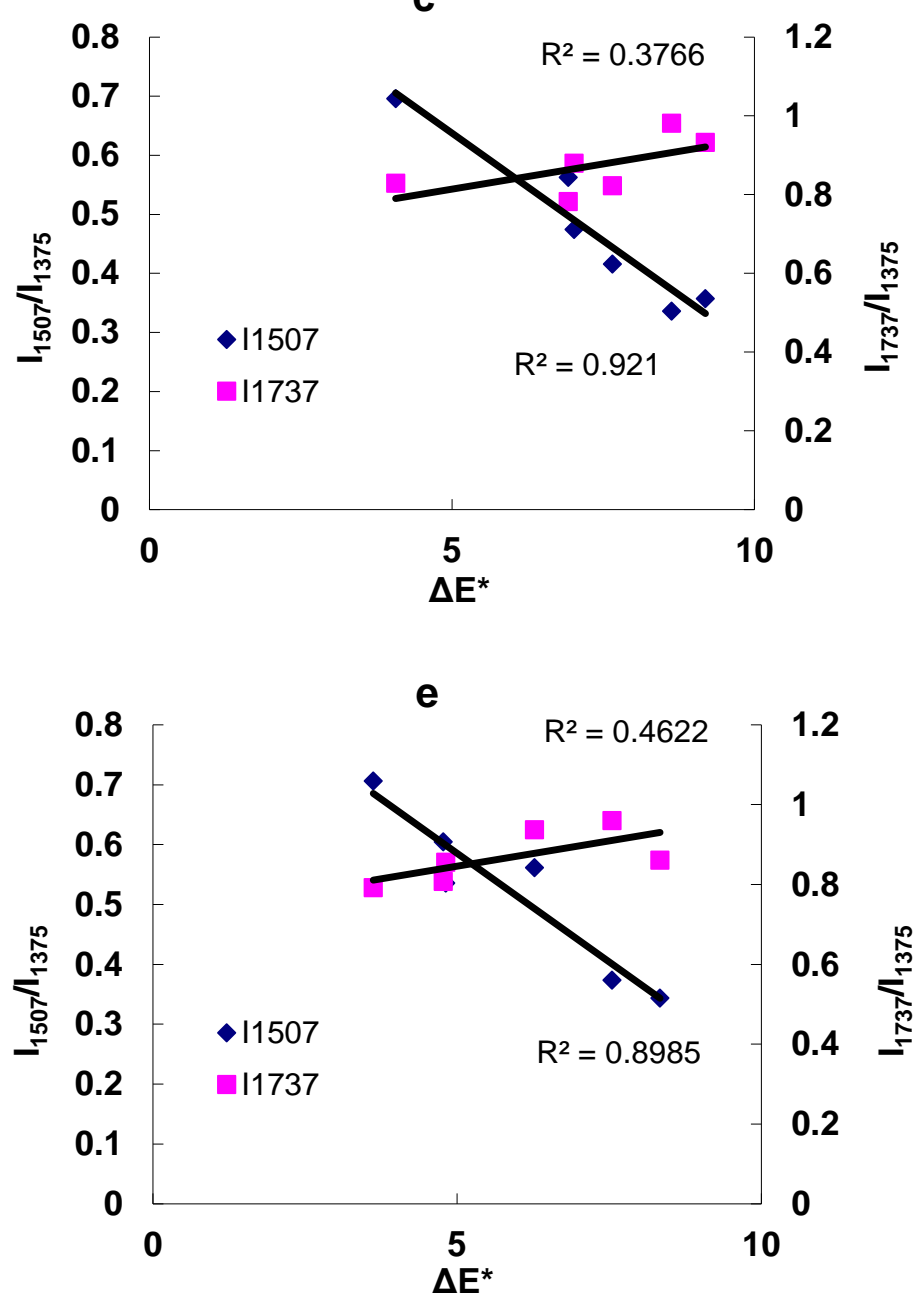

b

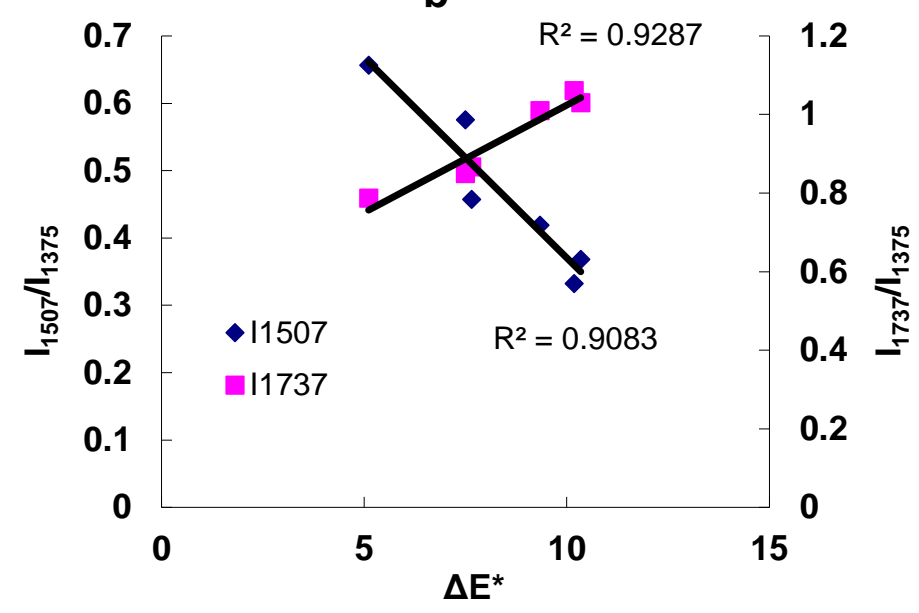

d
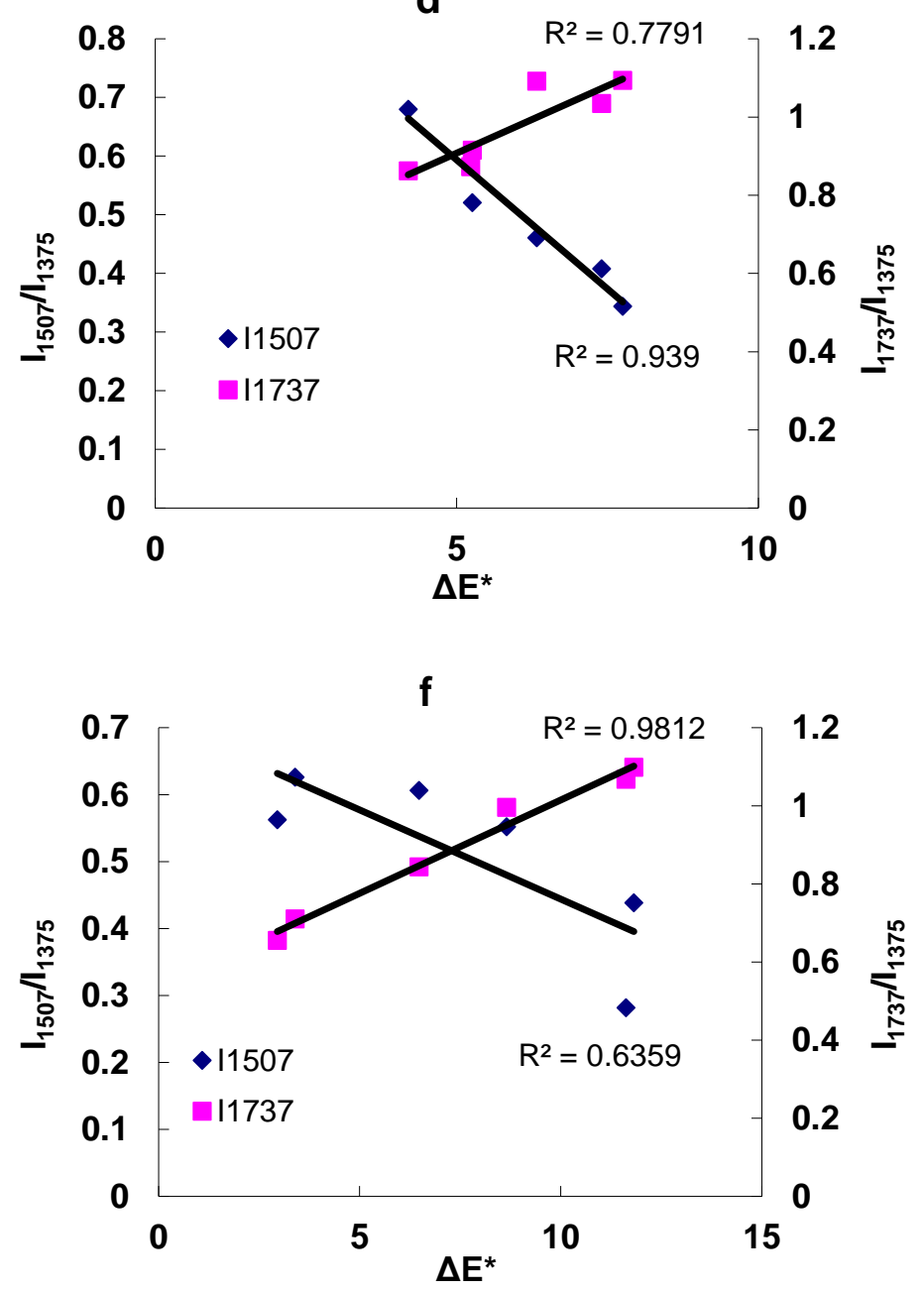

Fig. 14. Correlations of $\Delta E^{*}$ with the decay of lignin and formation of carbonyl groups during UV weathering of rubber wood: (a) untreated specimens, (b) specimens treated at $155^{\circ} \mathrm{C}$ for $2 \mathrm{~h}$, (c) specimens treated at $155^{\circ} \mathrm{C}$ for $6 \mathrm{~h}$, (d) specimens treated at $185^{\circ} \mathrm{C}$ for $2 \mathrm{~h}$, (e) specimens treated at $185^{\circ} \mathrm{C}$ for $6 \mathrm{~h}$, and (f) specimens treated at $215^{\circ} \mathrm{C}$ for $2 \mathrm{~h}$ 
Consistent with previous studies, nonconjugated carbonyl groups in all samples increased during UV irradiation; the difference was that the color change $\Delta E^{*}$ and the increase in carbonyl groups showed poor correlations in several kinds of specimens. It seems that the relationship between color change and the concentration of nonconjugated carbonyl groups was not as strong as that between color change and the decay of lignin.

\section{CONCLUSIONS}

1. The color variation patterns of heat-treated rubber wood under UV irradiation was greatly influenced by the thermal modification conditions.

2. When treated at mild conditions, the decline of $L^{*}$ value at the beginning period of irradiation and the various patterns of $a^{*}$ and $b^{*}$ were analogous to that of untreated samples, which might be due to the fact that the lignin and cellulose were barely modified by the heat treatment, as demonstrated by FTIR Spectra.

3. When treated at severe conditions, the correlation between $\Delta E^{*}$ and lignin photodegradation was destroyed, and the color performances of rubber wood under UV light changed fundamentally compared to untreated samples, which might be due to the deep modification of lignin and the generation of abundant extractives.

4. In both treated and untreated samples, lignin degraded rapidly under UV light radiation, and non-conjugated carbonyl groups generated correspondingly. It seemed that the photostability of lignin was not improved, no matter treated at what conditions.

\section{ACKNOWLEDGMENTS}

The authors are grateful for the support of the Natural Science Foundation of Hainan Province (317280) and the Central Public-interest Scientific Institution Basal Research Fund for the Chinese Academy of Tropical Agricultural Sciences (1630022017013). We also thank the support from the Key Laboratory of Biology and Genetic Resources of Rubber Tree, Ministry of Agriculture and Rural Affairs, P. R. China and the State Key Laboratory Incubation Base for Cultivation and Physiology of Tropical Crops.

\section{REFERENCES CITED}

Ahajji, A., Diouf, P. N., Aloui, F., Elbakali, I., Perrin, D., Merlin, A., and George, B. (2009). "Influence of heat treatment on antioxidant properties and colour stability of beech and spruce wood and their extractives," Wood Science and Technology 43(1-2), 69-83. DOI: $10.1007 / \mathrm{s} 00226-008-0208-3$

Argyropoulos, D. S., Heitner, C., and Schmidt, J. A. (1995). “Observation of quinonoid groups during the light-induced yellowing of softwood mechanical pulp," Research on Chemical Intermediates 21(3-5), 263-274. DOI: 10.1007/BF03052257

Ayadi, N., Lejeune, F., Charrier, F., Charrier, B., and Merlin, A. (2003). "Color stability of heat-treated wood during artificial weathering," Holz als Roh- und Werkstoff 61(3), 
221-226. DOI: 10.1007/s00107-003-0389-2

Bekhta, P., and Niemz, P. (2003). "Effect of high temperature on the change in color, dimensional stability and mechanical properties of spruce wood," Holzforschung 57(5), 539-546. DOI: 10.1515/HF.2003.080

Boonstra, M. J., Tjeerdsma, B. F., and Groeneveld, H. A. C. (1998). Thermal Modification of Non-durable Wood Species 1.The PLATO Technology: Thermal Modification of Wood (IRG/WP 98-40123), International Research Group on Wood Preservation, Stockholm, Sweden.

Brischke, C., Welzbacher, C. R., Brandt, K., and Rapp, A. O. (2007). "Quality control of thermally modified timber: Interrelationship between heat treatment intensities and CIE L*a*b* color data on homogenized wood samples," Holzforschung 61(1), 19-22. DOI: $10.1515 /$ HF.2007.004

Brosse, N., El Hage, R., Chaouch, M., Pétrissans, M., Dumarçay, S., and Gérardin, P. (2010). "Investigation of the chemical modifications of beech wood lignin during heat treatment," Polymer Degradation and Stability 95(9), 1721-1726. DOI: 10.1016/j.polymdegradstab.2010.05.018

Collier, W. E., Schultz, T. P., and Kalasinsky, V. F. (1992). "Infrared study of lignin: reexamination of aryl-alkyl ether C-O stretching peak assignments," Holzforschung 46(6), 523-528. DOI: 10.1515/hfsg.1992.46.6.523

Colom, X., Carrillo, F., Nogués, F., and Garriga, P. (2003). "Structural analysis of photodegraded wood by means of FTIR spectroscopy," Polymer Degradation and Stability 80(3), 543-549. DOI: 10.1016/s0141-3910(03)00051-x

Esteves, B., Domingos, I., and Pereira, H. (2008a). "Pine wood modification by heat treatment in air," BioResources 3(1), 142-154. DOI: 10.15376/biores.3.1.142-154

Esteves, B., Graça, J., and Pereira, H. (2008b). "Extractive composition and summative chemical analysis of thermally treated eucalypt wood," Holzforschung 62(3), 344351. DOI: $10.1515 /$ HF.2008.057

Esteves, B., and Pereira, H. (2009). "Wood modification by heat treatment: A review," BioResources 4(1), 370-404. DOI: 10.1515/HF.2009.036

Esteves, B., Marques, A. V., Domingos, I., and Pereira, H. (2013). "Chemical changes of heat treated pine and eucalypt wood monitored by FTIR," Maderas. Ciencia y Tecnología 15(2), 245-258. DOI: 10.4067/s0718-221x2013005000020

Evans, P. A. (1991). 'Differentiating 'hard' from 'soft' woods using Fourier transform infrared and Fourier transform spectroscopy," Spectrochimica Acta Part A: Molecular Spectroscopy 47(9-10), 1441-1447. DOI: 10.1016/0584-8539(91)80235-b

Faix, O. (1991). "Classification of lignins from different botanical origins by FT-IR spectroscopy," Holzforschung 45(s1), 21-27. DOI: 10.1515/hfsg.1991.45.s1.21

Faix O. (1992). "Fourier transform infrared spectroscopy," in: S. Y. Li and C. W. Dence (eds.), Methods in Lignin Chemistry, Springer-Verlag, Berlin, pp. 83-109. DOI: 10.1007/978-3-662-04931-0

Funaoka, M., Kako, T., and Abe, I. (1990). "Condensation of lignin during heating of wood," Wood Science and Technology 24(3), 277-288. DOI: 10.1007/BF01153560

González-Peña, M. M., and Hale, M. D. C. (2009). "Colour in thermally modified wood of beech, Norway spruce and Scots pine. Part 1: Colour evolution and colour changes," Holzforschung 63(4), 385-393. DOI: 10.1515/HF.2009.078

Grelier, S., Castellan, A., and Kamden, D. P. (2000). "Photoprotection of copper-aminetreated pine," Wood and Fiber Science 32(2), 196-202.

Hakkou, M., Pétrissans, M., Gérardin, P., and Zoulalian, A. (2006). "Investigations of the 
reasons for fungal durability of heat-treated beech wood," Polymer Degradation and Stability 91(2), 393-397. DOI: 10.1016/j.polymdegradstab.2005.04.042

Harrington, K. J., Higgins, H. G., and Michell, A. J. (1964). "Infrared spectra of Eucalyptus regnans F. Muell. and Pinus radiata D. Don," Holzforschung 18(4), 108113. DOI: $10.1515 / \mathrm{hfsg} .1964 .18 .4 .108$

Hergert, H. L. (1971). "Infrared spectra," in: Lignins, Occurrence, Formation, Structure and Formation, K. V. Sarkanen and C.H. Ludwig (eds.), Wiley-Interscience, New York, pp. 267-298.

Higgins, H. G., Stewart, C. M., and Harrington, K. J. (1961). "Infrared spectra of cellulose and related polysaccharides," Journal of Polymer Science Part A: General Papers 51, 59-84. DOI: 10.1002/pol.1961.1205115505

Hon, D. N. S., and Chang, S. T. (1984). "Surface degradation of wood by ultraviolet light," Journal of Polymer Science: Polymer Chemistry Edition 22(9), 2227-2241. DOI: $10.1002 /$ pol.1984.170220923

Hon, D. N. S., and Chang, S. T. (1985). "Photoprotection of wood surfaces by wood-ion complexes," Wood and Fiber Science 17(1), 92-100. DOI: 10.1177/004051758505501210

Hon, D. N. S., and Feist, W. C. (1986). "Weathering characteristics of hardwood surfaces," Wood Science and Technology 20(2), 169-183. DOI: 10.1007/BF00351028

Huang, X., Kocaefe, D., Kocaefe, Y., Boluk, Y., and Pichette, A. (2012). “A spectrocolorimetric and chemical study on color modification of heat-treated wood during artificial weathering," Applied Surface Science 258(14), 5360-5369. DOI: 10.1016/j.apsusc.2012.02.005

Jämsä, S., Ahola, P., and Viitaniemi, P. (2000). "Long-term natural weathering of coated ThermoWood," Pigment \& Resin Technology 29(2), 68-74. DOI: 10.1108/03699420010317807

Jämsä, S., and Viitaniemi, P. (2001). "Heat treatment of wood - Better durability without chemicals," in: Proceedings of Special Seminar, Antibes, France.

Kishino, M., and Nakano, T. (2004). "Artificial weathering of tropical woods. Part 2: Color change," Holzforschung 58(5), 558-565. DOI: 10.1515/hf.2004.085

Kocaefe, D., Poncsak, S., and Boluk, Y. (2008). "Effect of thermal treatment on the chemical composition and mechanical properties of birch and aspen," BioResources 3(2), 517-537.

Li, M., Li, X.-w., Qin, S.-S., Li, J.-n., Lin, W.-f., and Xie, G.-s. (2011). "Influence of heat treatment temperature of physical properties rubber wood," China Wood Industry 25(4), 47-49.

Liang, C. Y., and Marchessault, R. H. (1959). "Infrared spectra of crystalline polysaccharides. II. Native celluloses in the region from 640 to $1700 \mathrm{~cm}^{-1}$," Journal of Polymer Science 39(135), 269-278. DOI: 10.1002/pol.1959.1203913521

Lin, S. Y., and Kringstad, K. P. (1970). "Photosensitive groups in lignin and lignin model compounds," TAPPI 53(4), 658-663.

Marchessault, R. H. (1962). "Application of infra-red spectroscopy to cellulose and wood polysaccharides," Pure and Applied Chemistry 5(1-2), 107-130. DOI:

10.1351/pac196205010107

Marchessault, R. H., and Liang, C. Y. (1962). "The infrared spectra of crystalline polysaccharides. VIII. Xylans," Journal of Polymer Science 59(168), 357-378. DOI: 10.1002/pol.1962.1205916813

Muasher, M., and Sain, M. (2006). "The efficacy of photostabilizers on the color change 
of wood filled plastic composites," Polymer Degradation and Stability 91(5), 11561165. DOI: 10.1016/j.polymdegradstab.2005.06.024

Müller, U., Rätzsch, M., Schwanninger, M., Steiner, M., and Zöbl, H. (2003). "Yellowing and IR-changes of spruce wood as result of UV-irradiation," Journal of Photochemistry and Photobiology B: Biology 69(2), 97-105. DOI: 10.1016/S10111344(02)00412-8

Norrström, H. (1969). "Light absorbing properties of pulp and pulp components," Svensk Papperstidning 72(2), 25-38.

Nuopponen, M., Wikberg, H., Vuorinen, T., Maunu, S. L., Jämsä, S., and Viitaniemi, P. (2004). "Heat-treated softwood exposed to weathering," Journal of Applied Polymer Science 91(4), 2128-2134. DOI: 10.1002/app.13351

Pandey, K. K. (2005a). "A note on the influence of extractives on the photo-discoloration and photo-degradation of wood," Polymer Degradation and Stability 87(2) 375-379. DOI: 10.1016/j.polymdegradstab.2004.09.007

Pandey, K. K. (2005b). "Study of the effect of photo-irradiation on the surface chemistry of wood," Polymer Degradation and Stability 90(1), 9-20. DOI:

10.1016/j.polymdegradstab.2005.02.009

Petric, M., Kricej, B., Humar, H., Pavlic, M., and Tomazic, M. (2004). "Patination of cherry wood and spruce wood with ethanolamine and surface finishes," Surface Coatings International Part B: Coatings Transactions 87(3), 195-201. DOI: 10.1007/BF02699635

Popper, R., Niemz, P., and Eberle, G. (2005). "Investigations on the sorption and swelling properties of thermally treated wood," Holz als Roh- und Werkstoff 63(2), 135-148. DOI: 10.1007/s00107-004-0554-2

Sarkanen, K. V., Chang, H-M., and Ericsson, B. (1967). "Species variation in lignins. I. Infrared spectra of guaiacyl and syringyl models," TAPPI 50(11): 572-575.

Severo, E. T. D., Calonego, F. W., Sansígolo, C. A., and Bond, B. (2016). “Changes in the chemical composition and decay resistance of thermally-modified Hevea brasiliensis wood," PloS One 11(3), 1-10. DOI: 10.1371/journal.pone.0151353

Shen, H., Cao, J., Sun, W., and Peng, Y. (2016). "Influence of post-extraction on photostability of thermally modified scots pine wood during artificial weathering," BioResources 11(2), 4512-4525. DOI: 10.15376/biores.11.2.4512-4525

Srinivas, K., and Pandey, K. K. (2012). "Photodegradation of thermally modified wood," Journal of Photochemistry and Photobiology B: Biology 117, 140-145. DOI: 10.1016/j.jphotobiol.2012.09.013

Sundqvist, B. (2004). Colour Changes and Acid Formation in Wood during Heating, Ph.D. Dissertation, Luleå University of Technology, Skellefteå, Sweden.

Tjeerdsma, B. F., Boonstra, M., Pizzi, A., Tekely, P., and Militz, H. (1998). "Characterisation of thermally modified wood: Molecular reasons for wood performance improvement," Holz Als Roh-Und Werkstoff 56(3), 149-153. DOI: $10.1007 / \mathrm{s} 001070050287$

Tjeerdsma, B. F., and Militz, H. (2005). "Chemical changes in hydrothermal treated wood: FTIR analysis of combined hydrothermal and dry heat-treated wood," Holz als Roh- und Werkstoff 63(2), 102-111. DOI: 10.1007/s00107-004-0532-8

Tolvaj, L. and Faix, O. (1995). "Artificial ageing of wood monitored by DRIFT spectroscopy and CIE $L * a * b *$ color measurements 1 . Effect of UV light," Holzforschung 49(5), 397-404. DOI: 10.1515/hfsg.1995.49.5.397

Vernois, M. (2001). "Heat treatment of wood in France: State of the art," in: Proceedings 
of the Special Seminar: Environmental Optimization of Wood Protection, Antibes, France, pp. 39-46.

Wang, J. Y., and Cooper, P. A. (2005). "Effect of oil type, temperature and time on moisture properties of hot oil-treated wood," Holz als Roh- und Werkstoff 63(6), 417 422. DOI: $10.1007 / \mathrm{s} 00107-005-0033-4$

Wang, X.-q., Fei, B.-h., and Ren, H.-q. (2009). "FTIR spectroscopic studies of the photodiscoloration of Chinese fir," Spectroscopy and Spectral Analysis 29(5), 1272-1275. DOI: 10.3964/j.issn.1000-0593(2009)05-1272-04

Yildiz, S., Tomak, E. D., Yildiz, U. C., and Ustaomer, D. (2013). "Effect of artificial weathering on the properties of heat treated wood," Polymer Degradation and Stability 98(8), 1419-1427. DOI: 10.1016/j.polymdegradstab.2013.05.004

Yildiz, S., Ylidiz, U. C., and Tomak, E. D. (2011). "The effects of natural weathering on the properties of heat-treated alder wood," BioResources 6(3), 2504-2521.

Article submitted: June 10, 2019; Peer review completed: August 16, 2019; Revised version received and accepted; May 12, 2020; Published: May 19, 2020.

DOI: $10.15376 /$ biores. 15.3.5179-5197 